\title{
Influencer Marketing in the Growth Hacking strategy of digital brands
}

\author{
Patricia Coll*, Josep Lluís Micó**
}

*Universitat Oberta de Catalunya, Spain

**Universitat Ramon Llull, Spain

Abstract

\begin{abstract}
This article analyses the presence of influencer marketing in business communications strategies in the new economy, based on the results of an exploratory investigation carried out in accordance with the methodology of the Grounded Theory.

The categorisation of the information, obtained from the elaboration of the case studies of three digitally native brands (Wallapop, Westwing and Fotocasa), shows that influencer marketing actions are part of their $360^{\circ}$ communications strategy.

Actions with influencers are developed in a synergistic way with other advertising and public relations actions, both on and offline. In terms of their approach, they follow Marston's strategic planning model, which consists of four phases: research, planning, execution and evaluation. In this sense, its particularities include the decision-making based on data, as well as the empowerment of the user and the brands' agents.
\end{abstract}

Keywords: Influencer marketing, communications strategy, new economy, public relations, social media

Submitted: $2^{\text {nd }}$ October 2018

Accepted: $11^{\text {th }}$ February 2019

How to quote this article:

Coll, P., Micó, J.L. (2019). Influencer Marketing in the Growth Hacking strategy of digital brands. Observatorio, 13(2), 87-105.

\section{Introduction}

Word-of-mouth marketing has always had a great influence on public opinion and consumers and, therefore, plays a key role in the field of communication due to the added credibility it provides.

The arrival of the Internet and, above all, the emergence of social networks and the omnipresence of mobile communication has lead to an increase in the effect of word of mouth (Trusov et al., 2009), as well as in the number and variety of agents, including so-called influencers (Brown and Hayes, 2008). Based on this scenario, brands analyse, on the one hand, how to turn their own users into brand ambassadors (Weiss, 2014) and, on the other, how to reach them through their agents via influencer marketing strategies which, in turn, achieve virality (Rushkoff, 1994; Jurvetson and Draper, 1997; Berger and Milkman, 2012) for their messages.

Copyright (c) 2019 (Patricia Coll, Josep Lluís Micó). Licensed under the Creative Commons Attribution-NonCommercial Generic (cc by-nc). Available at http://obs.obercom.pt. 
In this new interconnected context (Castells, 2001), digitalisation transforms society and the world of business (Moreno, 2016), the birth place of the so-called new economy, a widely accepted concept since the director of Wired magazine, Kevin Kelly (Kelly, 1999), began to use it to define the new business ecosystem:

The new economy has three specific characteristics: it is global, it supports the intangible-ideas, information and relationships-and is highly interconnected. These three attributes generate a new type of market and society, which have their origins in the electronic networks that are present everywhere.

Kelly, 9 January 1997

One of the clearest descriptions of this concept of new economy was made by sociologist Manuel Castells during the inaugural lecture of the UOC's doctorate program on the society of information and knowledge:

The new economy is not the economy of the companies that produce or design the Internet, it is that of the companies that work with and via the Internet. That is the new economy and that is what is taking place all over the world. It is true that the development of the uses of the Internet begins in those high-tech companies and Internet equipment and software creation companies that apply the technology to their own organisation, but, from there, it spreads rapidly to all types of companies, creating a new model of business organisation.

Castells, 2001

In fact, although the new economy has been progressing for two decades, the concept continues to be used, both in the academic sphere and in the media, to differentiate it from the pre-interconnection scenario and enable the contextualisation of recent phenomena such as that of the virtual currency, bitcoin (Stegăroiu, 2018).

As the unstoppable process of transformation of the economy and society accelerates, extends and becomes normalised, the new typology of organisations that make up the new economy, which encompasses more and more sectors, takes on an increasingly collaborative character (Alonso and Miranda, 2016). These companies, some of them emerging (startups) and others already established, are led by digital natives and are gaining more and more ground in all sectors and areas of society, as Hallam points out in The Social Media Manifesto: "The new generation of business leaders is digitally native, that is, they have never experienced life without an internet connection, and it is easy to see that the future of business will neither be offline or online: it will be integrated." (Hallam, 2013: 146)

In this sense, people born in this new interconnected world, known as digital natives, are growing and acquiring more and more prominence in the fields of business and communication. Digital natives (Prensky, 2001) are people and companies that have always lived in this changing environment.

In the same way that people born in the digital context display common characteristics that have been encompassed in the concept of digital natives, digitally native companies also have them. These are the so- 
called startups, a concept that was first defined by Blank: "A startup is a temporary organisation used to search for a repeatable and scalable and business model." (Blank, 2013: 58)

Eric Ries, creator of the Lean Startup method, provides a second definition of the concept of startup, widely accepted in the academic field, which considers it "a human institution designed to create a new product or service under conditions of extreme uncertainty". (Ries, 2012: 14) According to Ries, the key to the functioning of startups is what he calls 'the minimum viable product', that allows for the launching of successive versions of a product to be able to measure its impact before completing its development: "The first step is to enter the construction phase as quickly as possible with a minimum viable product (MVP). An MVP is a version of a product that allows for a complete cycle of the build-measure-learn feedback loop with minimal effort and development time." (Ries, 2012: 16)

Communications management in startups has been the subject of much debate within the ecosystem of the entrepreneurial world. Thus, in 2010, the term 'growth hacker' (Ellis, 2010; Holiday, 2014; Patel and Taylor, 2014; Ellis and Brown, 2018) appeared for the first time in Sean Ellis' blog Startup Marketing to define the new profile of a startup's communications manager, a multi-disciplinary position whose role is to generate growth: "A growth hacker is a person whose main objective is growth. (...) They must possess the creativity to discover unique ways of boosting growth, in addition to testing or evolving techniques developed by other companies." (Ellis, 2010)

In accordance with Ellis' original approach (2010), Riobóo considers that growth hacking, which arose from the need of emerging companies for accelerated growth with the minimum possible investment, has become the new marketing:

Growth hacking is new marketing applied to the digital economy. It feeds on analytical thinking, experimentation, web metrics, social networks and, of course, the creativity of its professionals. Traditional advertising campaigns are being replaced by innovative and low cost alternatives. In this case, the investment does not consist of huge advertising budgets, but of time, experimentation, creativity and perseverance. But the faster the better. Like so many great ideas, growth hacking grew out of a need: that of the entrepreneurs who wanted to grow quickly but did not have the financial muscle to carry out traditional marketing campaigns. To counteract it, they developed techniques that allowed them to acquire customers in the fastest and most economical way possible, but without neglecting a basic foundation: that the product or service satisfy a real need of the consumer. With this as a starting point, it is about setting marketing objectives and experimenting with new techniques and tools and continuously measuring progress to find the optimal formula for acquiring and retaining customers.

Riobóo, 2016

One of the keys to growth hacking is decision-making based on data. As Avinash Kaushik, one of the most renowned experts in the field, points out, there is an immense field of possibilities to make intelligent decisions in marketing and communication based on the analytical study of data: 
We have access to a large number of free tools that we can use to assure our decisions on the web. These range from the tactical to the strategic, but they are all based on data. These decisions range from the content that must be included and on which page, the way to buy the right set of keywords for our search marketing campaigns, the way to find the audience with the correct demographic and psychographic profile for our business, to the ways of delighting visitors when they access our website.

Kaushik, 2010: 13

With the aim of reflecting on the role that influencer marketing plays in the communications strategy of brands belonging to the new economy, this investigation adopts an exploratory approach, opting for the Grounded Theory methodology applied to case studies, to be able to study two recent phenomena that are not often addressed in the academic field: influencer marketing and the new economy's communications strategy.

This article describes the communication strategies developed in the interconnected context of the new economy in Barcelona (Spain)-the European hub with the fifth highest number of startups (Catalonia Trade \& Investment, 2017), with more than 1,200 emerging technology companies (Atómica, 2017) and headquarters of the Mobile World Congress-and based on the hypothesis of the existence of a $360^{\circ}$ approach, descendant of integrated marketing communications.

The results of this research come from the case studies of three successful digitally native brands (Prensky, 2001) based in Barcelona (Wallapop, for buying and selling second-hand products; Westwing, for home decoration; and Fotocasa, for renting and selling property), with data collected through triangulation during the last three years and analysed by means of the Grounded Theory (Strauss and Corbin, 1967) methodology. The conclusions of the study show that their strategic planning consists of the four phases of the RACE model (Marston, 1963), but with the particularities derived from their growth hacker (Ellis, 2010) approach.

\section{Referential Framework}

\section{From Word of Mouth to Influencer Marketing}

At the beginning of the last century, one of the historical leaders of advertising, Pere Prat Gaballí, already pointed out the great effect that advertising made by people in their environment has on consumers (Prat Gaballí, 1917). Along the same lines, the phenomenon of opinion leaders was widely studied by leading authors in the field of communication and marketing. Among them, Katz and Lazarsfeld (1955) stand out, with their two-step flow of communication theory, which analyses the influence exerted by opinion leaders, as explained by Moragas: 
It is an analysis based on a sociometric survey on the influences received by a group of women (Decatur, Illinois) in their decision making on diverse topics, such as outings to the cinema, fashion, domestic consumption and public affairs, ultimately discovering that different people influence different things. By investigating the people who have received advice or information, and then subsequently interviewing those who have been identified as influential and then, in turn, those who have influenced influential people and how they received the information (...) the idea of the now famous two step flow of communication formula was discovered and further developed. Two steps of influence: from the media to opinion leaders and from opinion leaders to people in the community. (...) The messages circulate towards the great mass of the population through the filter and commentary of opinion leaders.

Moragas, 2011: 82

Everett Rogers was one of the first to introduce the concept of early adopters, to define those pioneering users who "tend to purchase products or services, especially of a technological nature, before they become mass market". (Fundéu, 14 September 2011) Rogers also examined the role of interpersonal relationships in the propagation of messages in his Diffusion of Innovations theory (1962), which analyses how, over time, an idea or product gains momentum and diffuses through a specific population or social system.

According to Trusov, Bucklin and Pauwels, word-of-mouth marketing is, in essence, older than public relations and advertising, and its effectiveness consists of consumers sharing their opinions, preferences or experiences with others (Trusov et al., 2009).

In the 2.0 world, people who act as agents or opinion leaders, defined by the term 'influencers', proliferate. In this sense, the Word of Mouth Marketing Association (WOMMA) defines 'influencer' as a person who has a greater than average scope or impact in a relevant market (WOMMA, 2010) and 'influencer marketing' as the process of identifying and communicating with influencers in support of a business objective (WOMMA, 2010). When in the 1960s, American sociologist Everett Rogers, in his Diffusion of Innovations theory (1962), analysed how interpersonal relationships between individuals of different profiles can enhance the propagation of ideas and trends, he laid the theoretical foundations of what we now define in marketing as influencers. According to Brown and Hayes (2008), influencer marketing arises from the need to influence the decision making of the target audience, taking into account that the number of agents has been expanded and diversified in the digital world.

Another model of influencer marketing goes back to Katz and Lazarsfeld's two-step flow of communication (1955), in their book Personal Influence: The Part Played by People in the Flow of Mass Communications, from which the term 'opinion leader' was popularised to define people who exert influence over others.

Influencer marketing has made a notable dent in the communication strategy of brands. In their study Working with Influencers (2016), ADECEC makes a series of recommendations to brands, among which they emphasise the importance of delimiting influencers according to their own objectives and establishing longterm strategies in relation to them. The influencer phenomenon is not exempt from debate, as noted by Micó 
(Vázquez et al., 2016) or Sánchez (17 March 2017) in pointing out that influencers have taken a very short time to enter the commercial apparatus.

Influencer marketing analysis has also recently incorporated the concept of micro-influencer, which, according to Marketing Roadmaps, is someone who actively uses their social channels to influence their environment and, therefore, can be taken into account in communications strategies, adding the small actions of many influential people, organised around a single message (Marketing Roadmaps, 18 April 2017). To amplify this effect, Weiss recommends empowering fans and users so they can become brand ambassadors:

Invite the most positive and enthusiastic followers and those with influence and personal connections to use their power to become brand ambassadors who spread your message and engage proactively with your target consumers. Train your fan base. Allow opinion makers to determine how they want to share information and act as ambassadors at events.

Weiss, 2014: 16

Among the effects that are achieved with an influencer marketing strategy, virality stands out. It was first pointed out as a communications phenomenon by Rushkoff (1994), in his book Media Virus, in which he explained that if a message (understood metaphorically as a biological virus) reaches a susceptible user, that user will be "infected" and then be able to "infect" more susceptible users.

The widely accepted concept of viral marketing was coined by Jurvetson and Draper (1997). Since then, the factors that facilitate virality have been analysed continuously. Among the most accepted theories in this regard is the one developed by Berger and Milkman (2012), who pointed out the complex relation between emotion and social transmission.

\section{Influencer Marketing in Communications Strategies}

Influencer marketing is one of the fields of action that ADECEC (2008) includes in so-called marketing communication, which includes the set of public relations techniques used by marketing to achieve its objectives (Estanyol et al., 2016: 41). However, according to De Aguilera (2016), marketing communication encompasses the new techniques that are on the border between advertising and public relations, such as branded content, influencer marketing and content marketing.

As García Carballo points out, the raison d'être of marketing communication lies in that "users reject any type of message that is of a purely commercial nature, with the characteristics of advertising messages and, therefore, organisations resort to public relations, especially through social networks." (García Carballo, 2012: 145)

As we will see in the conclusions of this research, in addition, influencer marketing is not addressed in an isolated way, but is part of a communications strategy, that is, "an orientation of intervention, or an approach of action for a problem that is to be solved, or for a particular project to be carried out," (Xifra, 2007: 10) 
which is also addressed in an integrated manner, in line with the conception of Integrated Marketing Communications (IMC), that coordinates actions of diverse disciplines, such as marketing, publicity and public relations, to take advantage of synergies and gain coherence (Schultz and Kitchen, 2000; Kliatchko, 2005; McGrath, 2005; Schultz and Patti, 2009).

With the emergence of the Internet and social networks, the IMC concept has evolved towards $360^{\circ}$ communication (Véliz, 2006; Pintado and Sánchez, 2009; Sánchez, 2012).

When planning this strategy, the available academic literature collects hundreds of models that are, in essence, coincident (Bernays, 1923; Marston, 1963; Steinberg, 1975; Black, 2004; Long and Hazelton, 1987; Cutlip and Center, 2001; Matilla, 2008; L'Etang, 2009; Wilcox et al., 2012). As stated by Matilla (2007), the capital reference point is the spiral model constructed by Marston (1963) under the acronym RACE, a process made up of four stages: research, action planning, communication, and evaluation.

In the field of the new economy, the management of communications strategies has been one of the main subjects of debate. Thus, in 2010, the term growth hacker (Ellis, 2014; Holiday, 2014; Patel and Taylor, 2014) appears for the first time in the Sean Ellis' Startup Marketing blog to define the new professional profile characterised by having the creativity to discover unique ways of boosting growth, in addition to testing or evolving previously tested techniques (Ellis, 2014).

\section{Methodology}

As indicated in the referential framework, word-of-mouth marketing is a long-term phenomenon. However, the rise of influencer marketing has taken an exponential leap with the emergence of social networks and, thus, we can consider its inclusion in communications strategies as a recent phenomenon, especially in the new economy sector (Kelly, 1999), which is also in itself another scarcely studied area of knowledge.

Therefore, the research presented in this article has an exploratory character and a qualitative approach (Taylor and Bogdan, 1984; Ruiz, 2012), and opts for the methodology of analysis of the Grounded Theory, which allows for the development of a theory based on data that has been collected and analysed systematically. This approach has been applied in social sciences, and especially in studies related to communications in recent phenomena (Serrano, 2017; Cassany, 2016; Estanyol, 2014; Tucker-McLaughlin and Campbell, 2012).

The definition of this methodology comes from Strauss and Corbin:

The Grounded Theory is a general methodology for developing a theory based on data collected and analysed systematically. The theory evolves during real research, and it does so through the continuous interaction between analysis and data collection.

Strauss and Corbin, 1998: 273 
Glaser would provide the following definition:

The Grounded Theory is a methodology of analysis linked to the collection of data, which uses a set of systematically applied methods to generate an inductive theory about a substantive area. The final research product constitutes a theoretical formulation, or an integrated set of conceptual hypotheses, about the substantive area that is the object of study.

Glaser, 1992: 30

The theory evolves during real research, and it does so through the continuous interaction between analysis and data collection (Strauss and Corbin, 1998: 273). By virtue of this method, the research is based on an open research question, focused on exploring the characteristics of the new economy's communications strategy and stemming from the hypothesis of the existence of a $360^{\circ}$ approach, descendant of integrated marketing communications, which includes influencer marketing as a field of action.

The results of the research presented in this article derive from the case studies (Yin, 1994) of three digitally native brands (Wallapop, Westwing, and Fotocasa). The case studies have been constructed following the same structure, after categorising, as the Grounded Theory indicates, the data obtained from successive indepth interviews, observation and documentary analysis using the triangulation method (Leavy, 2017).

Specifically, this research consists of three phases of in-depth, successive and complementary interviews with different professionals involved in the communications strategy of the three new economy brands under study, as well as in the execution of their different communications actions, among which, as we will see in the conclusions, are those of influencer marketing. The interviewees who participated in the three rounds of interviews were chosen by each brand according to the needs expressed by the authors of the research during each of its phases. The aim of the first phase was to carry out an initial exploration of the strategic planning of each brand's communications. The second, in conjunction with the team, addressed the fields of action of communications that are used and how they execute the strategy. And, finally, the third phase was aimed at pooling the preliminary hypotheses and conclusions, following an initial analysis categorised after the triangulation of the data obtained during the interviews, field observation and documentary analysis.

Field observation allows for the surveying of the scene both before and during the interviews, in order to better interpret the information provided by the subjects of study. This process of observation, carried out over three years, is considered long-term taking into account that it is framed within the ecosystem of the new economy.

In parallel, and in addition to the annotations and records of the observation and interviews, the gathering of data includes the collection and analysis of more than 12,000 documents, among them briefings, timelines, press clippings, content generated on the Internet, on social networks and in apps, as well as graphic and audiovisual material.

Once the triangulation was carried out, and after verifying that a point of information saturation was reached both between cases and subjects of study, the investigation proceeded to the categorisation of concepts 
detected in the cases, following the principles of the Grounded Theory, to be able to detect coincidences that would allow for the presentation and analysis of the results of the study and to draw the conclusions that are presented in this article.

\section{Results and Discussion}

As indicated in the methodology, by adhering to the principles of the Grounded Theory, the research has categorised the concepts obtained following the triangulation of the information acquired during the successive phases of interviews, documentary analysis and observation of the three cases under study (Wallapop, Westwing and Fotocasa).

\section{Case Studies}

The study of the cases of new economy brands allows us to detect the presence of communications actions focused on influencer marketing which, as analysed in the conclusions of this article, form part of a $360^{\circ}$ communications and growth hacking strategy. Therefore, as is presented in all of the case studies presented below, communications actions with influencers are outlined, planned and executed in a synergistic way together with actions from other areas of advertising and relations such as publicity, the organisation of events or content marketing, which are constantly monitored to evaluate the fulfilment of their clear and measurable objectives.

Wallapop

The geolocalised second hand market platform Wallapop employs influencer marketing for its corporate social responsibility strategy.

The influencer marketing action the company developed consisted of the solidary campaign "Objects with History", which took place in December 2016. With the aim of communicating that Wallapop is not just a wall of objects but an open book full of interesting moments and stories to be discovered, with this campaign the app directed its line of corporate social responsibility towards the memory of objects on behalf of the Pasqual Maragall Foundation, which fights against Alzheimer's disease: a brain disease that is characterised precisely by causing memory loss.

Among the objects with history donated by famous people were a leather jacket belonging to publicist and television presenter Risto Mejide, the dress television presenter Anne Igartiburu wore during a New Year's Eve television special, a book signed by author Boris Izaguirre, and designer brand sandals worn by models Vanesa Lorenzo and Judit Mascó. The campaign spread through social networks, through users and participating 
influencers' app accounts, and also via the media, through the dissemination of a press release explaining the action which included audiovisual material (Chance, 5 December 2016; Roca, 7 December 2016).

Figure 1: Objects with History campaign

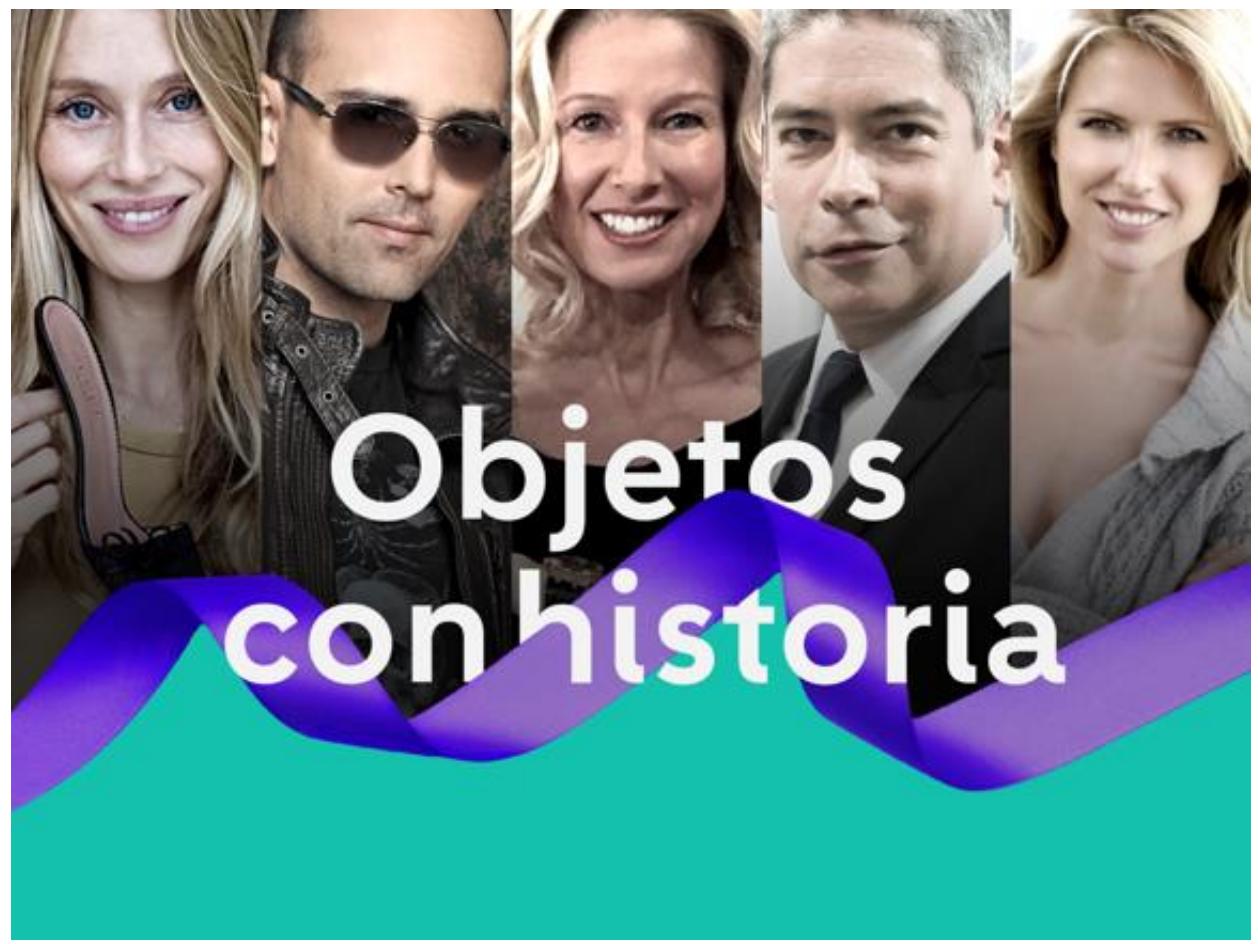

Source: Wallapop

\section{Westwing}

The documentary analysis and observation carried out in the case study of home decoration website Westwing confirm the presence of influencer marketing as the axis of one of its main content marketing and press office actions, which is titled \#40preguntasmuyWestwing (Westwing, July 2016).

The integrated communications and public relations strategy of the firm revolves around this action, which disseminates interviews with celebrities through social networks, press releases and even press lunches, such as the one they organised with fashion designer Ágatha Ruiz de la Prada as guest. 
Figure 2: \#40preguntasmuyWestwing, with Ágatha Ruiz de la Prada.

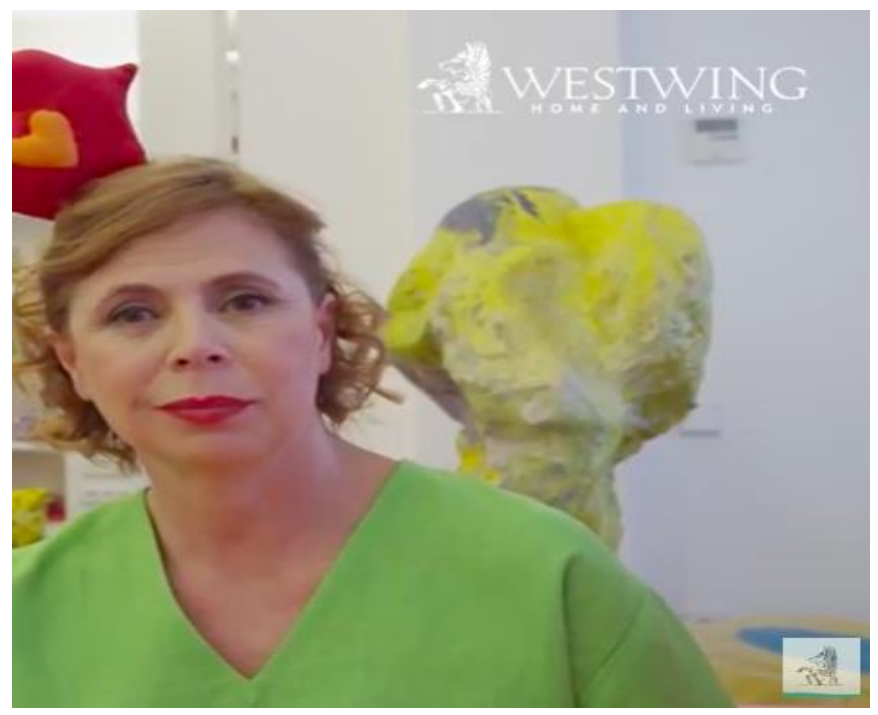

Source: Westwing

\section{Fotocasa}

Property website Fotocasa generates content relating to the evolution of the average price of housing in Spain (both for sale and for rent), which it presents at press conferences and distributes to the media and influencers to position the portal as an informative point of reference. In addition, it also publishes content generated by property market influencers, with actions such as El libre blanco del alquiler [White Rent Book] (Fotocasa, 22 March 2017), written by these experts and made viral in conjunction with the firm. 
Figure 3: Fotocasa's White Rent Book

Libro blanco

Tendencias del mercado del alquiler

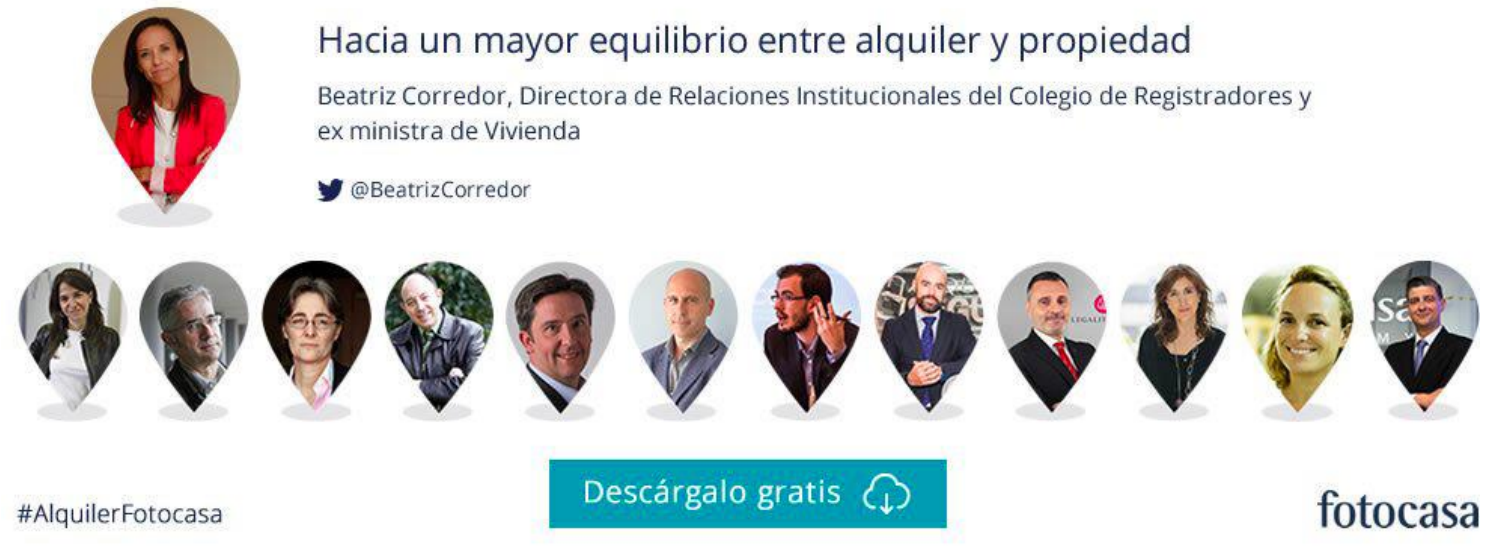

Source: Fotocasa

Beyond the property sector, and with the aim of reaching a wider audience, Fotocasa also organises specific actions with influencers, such as the \#FotocasaParty events, which celebrate the inauguration of the new houses of celebrity couples who find their home through the portal. The protagonists of the first edition of the \#FotocasaParty, in 2016, were Alaska and Mario Vaquerizo (Fotocasa, 16 March 2016; Fotocasa, 15 April 2016; Fotocasa, 22 April 2016; Fotocasa, 3 June 2016) and those of the second edition, in 2017, were Lidia Torrent and Matías Roure from television programme First Dates (Fotocasa, 10 May 2017). Both events, to which various media channels were invited, were disseminated by raffling tickets via social networks among the platform's users. 
Figure 4: \#FotocasaParty with Alaska and Mario

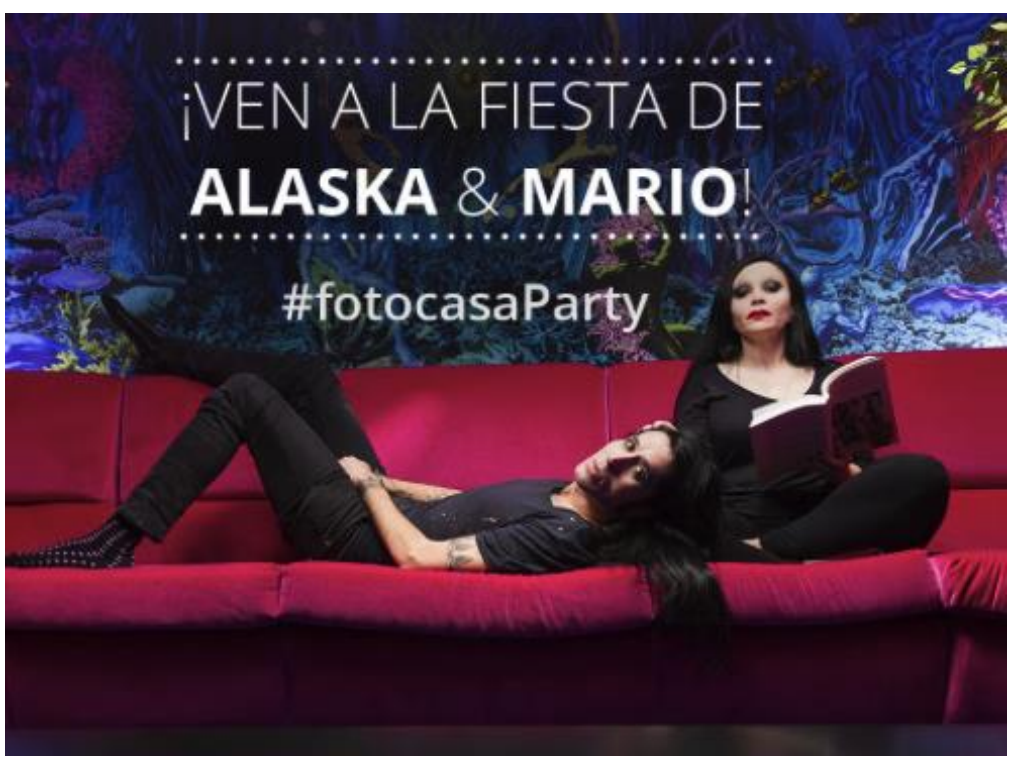

Source: Fotocasa

The portal also organises \#retoFotocasa (Fotocasa, 7 November 2016), which was created when the finalist of television cooking contest MasterChef, Fabián León, challenged Spain's main property websites to find him an apartment in exchange for a cooking class. It ended up becoming an event attended by various cuisine and lifestyle influencers, such as Laura Ponts and Delicious Martha.

\section{Categorisation}

Following the principles of the Grounded Theory (Strauss and Corbin, 1998), as shown in Table 1, once the information has been categorised, a cross-sectional comparison has been made, indicating the presence or non-presence of the key concepts addressed in the theoretical framework, including those referring to the fields of action of public relations and their conception and strategic planning.

Table 1: Categorisation

\begin{tabular}{|l|l|}
\hline CATEGORY & DETECTED \\
\hline $360^{\circ}$ strategy & $\mathrm{X}$ \\
\hline Investigation & $\mathrm{X}$ \\
\hline Planning & $\mathrm{X}$ \\
\hline Execution & $\mathrm{X}$ \\
\hline Evaluation & $\mathrm{X}$ \\
\hline Content marketing & $\mathrm{X}$ \\
\hline
\end{tabular}




\begin{tabular}{|l|l|}
\hline Influencer marketing & $\mathrm{X}$ \\
\hline Publicity & $\mathrm{X}$ \\
\hline Growth hacking & $\mathrm{X}$ \\
\hline
\end{tabular}

Source: own elaboration

In this sense, and in all the cases under study, we can observe the presence of influencer marketing, together with other actions that are included in the field of marketing communication as part of a $360^{\circ}$ communications strategy.

After analysing the categorisation, we can also observe a coincidence in the strategic planning of communications that responds to the four phases of the Marstonian RACE model for the strategic planning of public relations (Marston, 1963): reach, act, convert and engage. In this sense, communications action with influencers stem from a previous research process, are planned together with the influencer, they are executed taking advantage of synergies with other marketing communications actions (such as publicity or content marketing) and are evaluated with an almost real-time follow-up based on KPIs: measurable performance indicators that serve to calculate the return on investment.

\section{Conclusions}

The analysis made based on the categorisation carried out through the Grounded Theory method (Strauss and Corbin, 1998), displayed in Table 1, allows us to answer the main research question, which is focused on exploring the role that influencer marketing plays in the communications strategies of the new economy (Kelly, 1999; Castells, 2000). In this sense, we can affirm that actions with influencers are part of the communications strategies of the brands under study, which, in turn, have $360^{\circ}$ vision and are developed according to the four phases of the Marstonian strategic planning process (Marston, 1963): reach, act, convert and engage. Research and evaluation are key factors in a communications strategy involving influencers, seeing as decision-making is based on data.

In this sense, influencer marketing actions are generally combined with other marketing communication actions (ADECEC, 2008), among which content marketing and actions involving the media or publicity stand out. This results involve various considerations related to marketing management. First, communication determines the way to manage and it's necessary that there is a culture of a relational company. The new organizational systems are based on flexible collaborative cultures, close to the adhocracy (Mintzberg, 1979), more relational, in constant symbiosis with themselves and with the environment, holistic and adaptable. The company becomes more transversal, more diversified and more complex. Coordination between marketing teams are necessary.

This vision has implications in terms of organizational culture and its leadership (Schein, 1985), as well as the empowerment of the members of the organization (Kotter, 2012), since they work based on management by 
objectives (Drucker, 1954). for making decisions based on data. Also in strategic decisions of the company, aligned with its strategy of growth hacking (Ellis and Brown, 2018), including those that involve even shareholding, such as media for equity, as a way to obtain advertising space in exchange for transferring shares to large communication groups.

With regards to the methodology this research has been based on, applying the principles of Grounded Theory to the analysis of case studies through the triangulation of the data obtained from detailed interviews, documentary analysis and observation, the results of the study demonstrate the validity of the combination of qualitative methods. They furthermore enhance the appropriateness of Grounded Theory methodology for researching recent learning phenomena, such as growth hacking.

Regarding the methodology on which the present investigation is based, which applies the principles of the Grounded Theory to the analysis of case studies, elaborated by triangulating the data obtained based on indepth interviews, documentary analysis and observation, the results of the study also confirm the validity of the combination of both qualitative methods, as well as the suitability of the methodology of the Grounded Theory for the exploration of recent communications phenomena such as, in this case, influencer marketing in the field of the new economy.

\section{Bibliography}

ADECEC (2008). La comunicación y relaciones públicas en España-radiografía de un sector. Retrieved from: http://prnoticias.com/images/stories/comunicacion/ARCHIVOS/presentacin_del_estudio_adecec.pdf.

ADECEC (2016). Trabajar con influencers. Retrieved from: http://www.adecec.com/pdf/adecec_presenta_la_guia_\%E2\%80\%9Ctrabajar_con_influencers._formu las_para_una_relacion_eficaz\%E2\%80\%9D_.pdf.

Aguilera, J. de (2016). La gestión de cuentas en la agencia de comunicaciones de marketing. Barcelona: ESIC Editorial.

Alonso, M., and Miranda, A. (2016. La empresa colaborativa. Madrid: Pearson.

Berger, J., and Milkman, K. L. (2012). "What makes online content viral?". Journal of marketing research, 49 (2), p. 192-205. Retrieved from: http://journals.ama.org/doi/abs/10.1509/jmr.10.0353.

Bernays, E. L. (1923). Crystallizing Public Opinion. New York: Boni \& Liveright.

Black, S. (2004). ABC de las relaciones públicas. Barcelona: Gestión 2000.

Blank, S. (2013). El manual del emprendedor. Barcelona: Gestión 2000.

Brown, D., and Hayes, N. (2008). Influencer Marketing: Who Really Influences Your Costumers. Oxford: Elsevier.

Cassany, R. (2016). Especificitats de la narrativa audiovisual informativa a internet. Anàlisi dels vídeos produits per cibermitjans catalans. Barcelona: Universitat Pompeu Fabra. Retrieved from: http://hdl.handle.net/10803/385358 [accessed: 20 January 2018]. 
Castells, M. (2001). La galaxia Internet. Reflexiones sobre internet, empresa y sociedad. Barcelona: Plaza y Janés.

Castells, M. (2000). "Internet y la sociedad red. Lección inaugural del programa de doctorado sobre la sociedad de la información y el conocimiento de la Universitat Oberta de Catalunya (UOC) del curso 2000-2001". Retrieved from: http://www.uoc.edu/web/cat/articles/castells/castellsmain2.html.

Chance (5 December 2016). "Consigue objetos de segunda mano de tus estrellas favoritas y colabora contra el Alzheimer". Europa Press. Retrieved from: http://www.europapress.es/chance/tendencias/noticiaconsigue-objetos-segunda-mano-estrellas-favoritas-colabora-contra-alzheimer-20161205175943.html.

Cutlip, S. M., and Center, A. H. (2001). Relaciones públicas eficaces. Barcelona: Gestión 2000.

Drucker, P. (1954). The principles of management. New York: Harper \& Brothers.

Ellis, S. (2010). "Find a Growth Hacker for Your Startup". Startup Marketing. Retrieved from: http://www. startup-marketinq.com/where-are-all-the-growth-hackers.

Ellis, S., and Brown, M. (2018). El método Hacking Growth: Qué hacen compañías explosivas como Facebook, Airbnb y Walmart para ser líderes en el mercado. Barcelona: Penguin Random House.

Estanyol, E. (2014). Percepció i gestió de la creativitat en les empreses consultores de comunicació i relacions publiques. Universitat Autònoma de Barcelona. Retrieved from: http://hdl.handle.net/10803/283527.

Estanyol, E., Garcia, E., and Lalueza, F. (2016). ¿Cómo elaborar un plan de comunicación corporativa? Barcelona: Editorial UOC.

Fotocasa (22 March 2017). Libro blanco. Tendencias del mercado de alquiler. Retrieved from: https://www.fotocasa.es/blog/alquiler/libro-blanco-alquiler.

Fotocasa (16 March 2016). \#FotocasaParty con Alaska \& Mario. Retrieved from: https://www.youtube.com/watch?v=g9YIcSsjrOI.

Fotocasa (15 April 2016). \#FotocasaParty con Alaska \& Mario - El evento. Retrieved from: https://www.youtube.com/watch?v=KQPLmWiNyRE.

Fotocasa (22 April 2016). \#FotocasaParty con Alaska \& Mario - Ganadores del sorteo. Retrieved from: https://www.youtube.com/watch?v=9cqNuhYGXEQ.

Fotocasa (3 June 2016). Este es el rincón favorito de Alaska \& Mario, ¿cuál es el tuyo? \#MiRinconFavorito. Retrieved from: https://www.youtube.com/watch?v=yK5Q50Sgy3k.

Fotocasa (10 May 2017). \#FotocasaParty 2017 con Lidia y Matías. Retrieved from: https://www.youtube.com/watch?v=VeeU4PxKeGk.

Fotocasa (7 November 2016). El \#retoFotocasa reúne a los instagrammers de cocina y lifestyle más influyentes del momento. Retrieved from: http://prensa.Fotocasa.es/el-retoFotocasa-reune-a-losinstagrammers-de-cocina-y-lifestyle-mas-influyentes-del-momento.

Fundéu (14 September 2011). Usuarios pioneros o clientes madrugadores, mejor que 'early adopters'. Fundéu. Retrieved from: https://www.fundeu.es/recomendacion/usuarios-pioneros-o-clientes-madrugadoresmejor-que-early-adopters-1055. 
García Carballo, C. (2012). "Mensajes con fines publicitarios que tornan en relaciones públicas en las redes sociales. El caso de Starbucks España y Cash Converters España". Revista Internacional de Relaciones Públicas, 4, vol. II.

Glaser, B. G. (1992). Basics of Grounded Theory Analysis: Emergence Vs. Forcing. Mill Valley, CA: Sociology Press.

Hallam, J. (2013). The Social Media Manifesto. New York: Springer.

Holiday, R. (2014). Growth Hacker Marketing: A Primer on the Future of PR, Marketing, and Advertising. New York: Portfolio / Penguin.

Jurvetson, S., and Draper, T. (1997). "Viral marketing: Viral marketing phenomenon explained". DFJ Network News. Retrieved from: https://es.scribd.com/document/133798561/08-Tim-Draper-on-ViralMarketing.

Katz, E. and Lazarsfeld, P. (1955). Personal Influence. New York: Free Press.

Kaushik, A. (2010). Analítica web 2.0. El arte de analizar resultados y la ciencia de centrarse en el cliente. Barcelona: Gestión 2000.

Kelly, K. (1999). Nuevas reglas para la nueva economía. México: Ediciones Granica.

Kliatchko, J. (2005). "Towards a New Definition of Integrated Marketing Communications (IMC)". International Journal of Advertising, 24(1), 7-34.

Kotter, J. P. (2012). Leading change. Hrvard: Harvard business press.

L'Etang, J. (2009). "Public Relations and Diplomacy in a Globalized World: An Issue of Public Communication". American Behavioral Scientist, 53(4), 607-626. Retrieved from: http://journals.sagepub.com/doi/10.1177/0002764209347633.

Leavy, P. (2017). Research Design. New York: The Guilford Press.

Long, L. W., and Hazelton, V. (1987). "Public Relations: A Theoretical and Practical Response". Public Relations Review, 13 (2), 3-13.

Marston, J. E. (1963). The Nature of Public Relations. New York: McGraw-Hill.

Marketing Roadmaps (2017). Influencer Marketing Landscape 2017. Chatham: Newstex.

Matilla, K. (2008). Los modelos de planificación estratégica en la teoría de las relaciones públicas. Barcelona: Editorial UOC.

Matilla, C. (2007). Aportaciones para un modelo global de planificación estratégica en relaciones públicas y comunicación integral. Análisis de un caso: el uso de los modelos de planificación estratégica en algunas agencias y consultoras de relaciones públicas y comunicación. Barcelona: Universitat Autònoma de Barcelona.

McGrath, J. M. (2005). "At a Crossroads. A Theoretical Review and a Conceptual Framework for Testing". Marketing Management Journal, 15, 2, p. 55-66.

Mintzberg, H. (1979). The structuring of organizations. Englewood Cliffs NJ: Prentice Hall.

Moragas, M. (2011). Interpretar la comunicación. Barcelona: Editorial Gedisa.

Moreno, J. L. (2016). Transformación digital de los negocios. Madrid: The Valley Digital Business School. 
Patel, N., and Taylor, B. (2014). "The Definite Guide to Growth Hacking". QuickSprout. Retrieved from: https://www.quicksprout.com/the-definitive-guide-to-growth-hacking.

Pintado, T., and Sánchez, J. (2009). Imagen corporativa. Influencia en la gestión empresarial. Madrid. ESIC Editorial.

Prat Gaballí, P. (1992). Una nueva técnica. La publicidad científica. Barcelona: Cambra de Comerç de Barcelona [1st edition, 1917].

Prensky, M. (2001). "Digital Natives, Digital Immigrants". On the Horizon, 9 (5), p. 1-6.

Ries, E. (2012). El método Lean Startup. Cómo crear empresas de éxito utilizando la innovación continua. Barcelona: Grupo Planeta.

Riobóo, D. (4 May 2016). "El Growth Hacker, pieza clave para el posicionamiento". El País Retina. Retrieved from: https://retina.elpais.com/retina/2016/05/04/innovacion/1462333385_146233.html.

Roca, M. (7 December 2016). "Famosos contra el alzhéimer". El Periódico. Retrieved from: https://www.elperiodico.com/es/gente/20161207/los-famosos-ponen-su-granito-contra-el-alzheimer5673343.

Rogers, E. M. (1962). Diffusion of Innovations. New York: Free Press.

Ruiz, J. I. (2012). Metodología de la investigación cualitativa. Bilbao: Universidad de Deusto.

Rushkoff, D. (1994). Media Virus. New York: Random House Publishing Group.

Sánchez, P. (2017). "Influencers, de vocación a profesión". Ipmark. Retrieved from: http://ipmark.com/influencers-vocacion-profesion/.

Sánchez, J. (2012). Nuevas tendencias en comunicación. Madrid: ESIC Editorial.

Serrano, M. (2017). Más allá de la comunicación. Procesos de Advance Care Planning (toma de decisiones y planificación adelantada) en cuidados al final de la vida. Castellón: Universitat Jaume I. Retrieved from: http://hdl.handle.net/10803/404308.

Schein, E. H. (1985): Organizational Culture and Leadership. San Francisco: Jossey-Bass Publishers Schultz, D. E., and Kitchen, P. J. (2000). "A response to 'Theoretical concept or management fashion?"' Journal of Advertising Research, 4O5), 17-21. DOI: 10.2501/JAR-40-5-17-21.

Schultz, D. E., and Patti, C. H. (2009). "The evolution of IMC: IMC in a customer-driven marketplace". Journal of Marketing Communications, 15(2-3), 75-84. DOI: 10.1080/13527260902757480.

Steinberg, C. S. (1975). The Creation of Consent: Public Relations in Practice. Winter Park US: Hastings House Book Publishers.

Stegăroiu, C.-E. (2018). "The advantages and disadvantages of bitcoin payments in the new economy". Analele Universităţii Constantin Brâncuşi din Târgu Jiu: Seria Economie, 67-72.

Strauss, A., and Corbin, J. (1998). Basics of Qualitative Research: Techniques and Procedures for Developing Grounded Theory (2nd ed.). Thousand Oaks, CA: Sage.

Taylor, S. J., and Bogdan, R. (1984). Introducción a los métodos cualitativos de investigación. La búsqueda de significados. Barcelona: Paidós Ibérica.

Trusov, M., Bucklin, R. E., and Pauwels, K. (2009). "Effects of Word-of-mouth Versus Traditional Marketing: Findings from an Internet Social Networking Site". Journal of Marketing, 73 (5), p. 90-102. 
Tucker-McLaughlin, M., and Campbell, K. (2012). "A Grounded Theory Analysis: Hillary Clinton Represented as Innovator and Voiceless in TV News". Electronic News, 6 (1), 3-19. Retrieved from: http://journals.sagepub.com/doi/abs/10.1177/1931243112439388.

Vázquez, A. (coord.) (2016). 100 influencers a los que seguir. Barcelona: Blanquerna.

Véliz, F. (2006). "Cambio de mirada en las organizaciones. Comunicación en 360". Revista Latinoamericana de Comunicación, 93, p. 62-65.

Weiss, R. (2014). "Influencer marketing". Marketing Health Services, 34 (1), p. 16.

Westwing (July 2016). 40 preguntas muy Westwing-Ágatha Ruiz de la Prada. Retrieved from: https://www.youtube.com/watch?v=Poq0YmwCjEw\&t=159s.

Wilcox, D.L., Cameron, G.T., and Xifra, J. (2012). Relaciones públicas. Estrategias y tácticas ([10 $0^{\text {th }}$ ed.). Madrid: Pearson Educación.

Word of Mouth Marketing Association (2010). Influencer Handbook. Retrieved from: https://painepublishing.com/wp-content/uploads/2015/06/Influencer-Handbook-v4-2.pdf.

Xifra, J. (2007). Tècniques de les relacions públiques. Barcelona: Editorial UOC.

Yin, R. K. (1994). Case Study Research: Design and Methods. Thousand Oaks, CA: Sage Publications. 